Fothergill, P. G. \& Yeoman, M. M. (1957). J. gen. Microbiol. 17, 631-639

\title{
The Mineral Nutrition of Rhizopus stolonifer
}

\author{
By P. G. FOTHERGILL \\ Botany Department, King's College, Newcastle upon Tyne \\ AND M. M. YEOMAN \\ Botany Department, King's College, Newcastle upon Tyne
}

\begin{abstract}
SUMMARY: A series of experiments with culture media was carried out dealing with: (1) the action of different salts and their interaction in the medium; (2) the relation of the nitrogen source to the action of the salts; (3) the effect of the carbon source; (4) the proportionate influence of the salts in the medium; (5) the rate of growth. The results showed that this fungus grew well at $26^{\circ}$ with an initial $\mathrm{pH}$ value of 7.0-8.0 and a growth period of 6-7 days. Statistical analysis of the results showed: (a) that under the given conditions an aqueous medium containing: $4 \%(\mathrm{w} / \mathrm{v})$ glucose; $0.048 \mathrm{M}-\mathrm{K}_{2} \mathrm{HPO}_{4} ; 0.012 \mathrm{M}-\mathrm{MgSO}_{4} .7 \mathrm{H}_{2} \mathrm{O} ; 0.025 \mathrm{M}-\left(\mathrm{NH}_{4}\right)_{2} \mathrm{SO}_{4} ; 2$ p.p.m. $\mathrm{Zn}, \mathrm{Fe}$ and $\mathrm{Mn}$, produced optimal growth measured as mg. dry wt.; $(b)$ a balance did not exist between $\mathrm{KCl}, \mathrm{K}_{2} \mathrm{HPO}_{4}$ and $\mathrm{MgSO}_{4} ;(c)$ a balance did not exist between the concentration of glucose and $\left(\mathrm{NH}_{4}\right)_{2} \mathrm{SO}_{4} ;(d)$ a balance existed between $\mathrm{K}_{2} \mathrm{HPO}_{4}$ and $\left(\mathrm{NH}_{4}\right)_{2} \mathrm{SO}_{4} ;(e)$ this fungus could only utilize $\mathrm{KNO}_{3}$ or $\mathrm{Ca}\left(\mathrm{NO}_{3}\right)_{2}$ to a negligible extent, while the best source found for nitrogen was $\left(\mathrm{NH}_{4}\right)_{2} \mathrm{SO}_{4}$; the most available phosphorus source was $\mathrm{K}_{2} \mathrm{HPO}_{4} ;(f)$ the rate of growth followed a sigmoid curve in a nutritionally optimal solution but in the minimal solution used the onset of decline in dry weight was delayed; $(g)$ the importance of a balanced solution is that in suitable media the buffering action of the phosphate controls the onset of acidity inimical to growth.
\end{abstract}

The object of these experiments was to study the effect of the mineral constituents of the medium in which Rhizopus stolonifer Ehren. was grown. They were designed to show statistically whether or not a balance between the salts was necessary in order to produce a maximum yield of dry wt. mycelium. Such experiments were first carried out in this form by Talley \& Blank (1941) working with the parasitic fungus Phymatotrichum omnivorum and they reported that a balance between the salts was necessary for high mycelial yield. Fothergill \& Raine (1954), using complementary strains of Mucor heimalis, reported that balance alone was not of overriding importance in the growth of the fungus. Fothergill \& Asheroft (1955) with Venturia inaequalis, a parasite, found that a proper balance between the major mineral constituents of the medium was necessary.

\section{METHODS}

The strain of Rhizopus stolonifer Ehren. used in the experiments described below was isolated from the atmosphere of Newcastle upon Tyne. Single spore cultures were kept as stocks in 6 in. $\times \frac{3}{4}$ in. test tubes on potato glucose agar, usually in a refrigerator at $2^{\circ}$. The morphological and cultural characters of the fungus were not affected by subcultivation during the experimental 
period. In the experiments on nutrition inoculations were made into a final volume of $30 \mathrm{ml}$. sterile culture fluid in Hysil Erlenmeyer flasks (150 ml.) plugged with cotton wool and incubated at $26^{\circ}$. Sterile phosphate solution was added aseptically from a glass syringe after autoclaving in order to avoid any possible precipitation. The inoculum was obtained as a suspension of spores and mycelial fragments by adding $10 \mathrm{ml}$. sterile distilled water to a suitable agar slope, rotating and decanting off the liquid; $1 \mathrm{ml}$. was then added to each culture flask of liquid medium. It was found by experience that the exact amount of the inoculum did not appreciably affect growth within limits.

Each experiment was carried out in five replicates and $\mathrm{pH}$ measurements were taken before and after the experiments using a Cambridge $\mathrm{pH}$ meter. After the growing period the mycelia were filtered on to tared Whatman No. 5 filter papers, dried at $85^{\circ}$ for $24 \mathrm{hr}$., cooled in a desiccator and weighed; results were thus expressed as mg. dry weight. For preliminary experiments the following basal defined liquid medium $A$ was used : $4 \%$ (w/v) glucose; $0.008 \mathrm{~m}$ $\mathrm{K}_{2} \mathrm{HPO}_{4} ; 0.003 \mathrm{M}-\mathrm{MgSO}_{4} .7 \mathrm{H}_{2} \mathrm{O} ; 0.0125 \mathrm{M}-\left(\mathrm{NH}_{4}\right)_{2} \mathrm{SO}_{4} ; \mathrm{Zn}, \mathrm{Mn}$ and $\mathrm{Fe}$ at 2 p.p.m. Preliminary experiments with this medium indicated that the optimum temperature for maximum mycelial growth was $26^{\circ}$, although the fungus grows well from $16^{\circ}$ up to this temperature; an onset of decline in dry weight begins on the 6 th to 7 th day. Robbins (1924) stated that the optimum $\mathrm{pH}$ value for this fungus in liquid was $5 \cdot 5$, but experiments with our strain showed that any $\mathrm{pH}$ value between 7 and 8 was optimal; a real decrease in mycelial dry weight occurred at $\mathrm{pH} 6$ or less. Experiments also showed that Rhizopus stolonifer grew negligibly (7-9 mg. dry wt./mycelium) when $\mathrm{KNO}_{3}$ or $\mathrm{Ca}\left(\mathrm{NO}_{3}\right)_{2}$ were used, thus confirming Robbins's (1937) statements. Asparagine and $\left(\mathrm{NH}_{4}\right)_{2} \mathrm{SO}_{4}$ are good sources of nitrogen. With the 7-day growth period used in these experiments phosphate had to be supplied as orthophosphate and not as pyro- or meta-phosphate because these two latter forms gave a distinct lag in growth. Experiments were carried out to determine the concentration of each salt in the medium which produced a high dry weight of mycelium.

\section{RESULTS}

First factorial experiment: variation of amounts of $\mathrm{K}_{2} \mathrm{HPO}_{4}, \mathrm{MgSO}_{4}$ and $\mathrm{KCl}$ added

The preliminary experiments provided the range of variations on medium A which may be used as a basis of the factorial experiments. Talley \& Blank (1941) used $\mathrm{KCl}$ in their medium and it was used here. The medium of the first factorial experiment concerned the salts $\mathrm{K}_{2} \mathrm{HPO}_{4}, \mathrm{MgSO}_{4} .7 \mathrm{H}_{2} \mathrm{O}$, and $\mathrm{KCl}$. The $\mathrm{KCl}$ was present either at $0.002 \mathrm{M}$, or not added; chloride was always present in minute quantities in the Analar chemicals used. The $\mathrm{K}_{2} \mathrm{HPO}_{4}$ was used at $0.004,0.008$ and $0.012 \mathrm{M}$, while the $\mathrm{MgSO}_{4} .7 \mathrm{H}_{2} \mathrm{O}$ was at $0.0015,0.003$ and $0.0045 \mathrm{M}$. Thus eighteen possible solutions were set up each in five replicates, giving a total of 90 cultures in any one experiment. All cultures had an initial $\mathrm{pH}$ value suitable for good growth of this fungus. As growth proceeded the acidity uniformly increased to $c$. pH $2 \cdot 0$, when growth ceased. The results of 
this experiment are shown in Table 1 which includes the analysis of variance.

Hence, increasing the concentration of $\mathrm{K}_{2} \mathrm{HPO}_{4}$ from $0.004 \mathrm{M}$ to $0.012 \mathrm{M}$ markedly increased the dry weight of mycelium, whatever the concentration of $\mathrm{MgSO}_{4}$ or $\mathrm{KCl}$. The $\mathrm{KCl}$ level had no effect on dry weight. Increase of the $\mathrm{MgSO}_{4}$ concentration from $0.0015 \mathrm{M}$ to $0.0045 \mathrm{M}$ in some cases increased dry weight yield slightly but, on the whole, not to a statistically significant extent. There was no evidence that the level of one salt affected the response to others.

Table 1. Dry weight of mycelium and growth responses of Rhizopus stolonifer after 6-7 days growth at $\mathbf{2 6}^{\circ}$ on media with different concentrations of certain components

Concentrations of $\mathrm{K}_{2} \mathrm{HPO}_{4}: \mathrm{P}_{1}, \mathrm{P}_{2}, \mathrm{P}_{8}=0.004 \mathrm{M}, 0.008 \mathrm{M}, 0.012 \mathrm{M}$; of $\mathrm{MgSO}_{4}: \mathrm{Mg}_{1}, \mathrm{Mg}_{9}$, $\mathrm{Mg}_{8}=0.0015 \mathrm{M}, 0.003 \mathrm{M}, 0.0045 \mathrm{M}$; of $\mathrm{KCl}: 0.002 \mathrm{M}$ or none. Difference required between weights for odds of $99: 1=11.32 \mathrm{mg}$. for $\mathrm{K}_{2} \mathrm{HPO}_{4}$ and $\mathrm{MgSO}_{4}$ and $9 \cdot 02 \mathrm{mg}$. for $\mathrm{KCl}$. Results given as mg. mean dry wt./mycelium.

\begin{tabular}{ccccc} 
& \multicolumn{4}{c}{ No $\mathrm{KCl}$} \\
$\mathrm{Pg}_{1}$ & 92 & $\mathrm{Mg}_{2}$ & $\mathrm{Mg}_{3}$ & Mean \\
$\mathbf{P}_{2}$ & 103 & 112 & 106 \\
$\mathbf{P}_{3}$ & 162 & 148 & 148 & 153 \\
Mean & 126 & 127 & 133 &
\end{tabular}

General mean $=127 \cdot 6 \mathrm{mg}$. dry wt./flask.

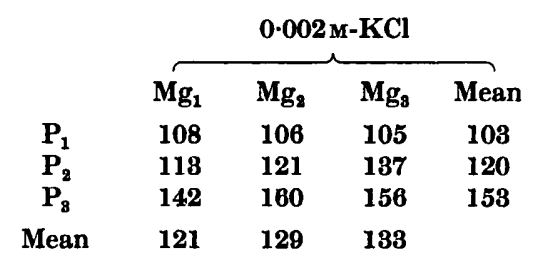

General mean $=126 \cdot 5 \mathrm{mg}$. dry wt. $/$ flask.

\section{Analysis of variance}

Required ' $F$ ' and ' $t$ ' values taken from Snedecor's tables (1934).

\begin{tabular}{|c|c|c|c|c|c|c|}
\hline \multirow[b]{2}{*}{ Variance } & \multirow[b]{2}{*}{ D.F. } & \multirow[b]{2}{*}{$\begin{array}{l}\text { Sum of } \\
\text { Squares }\end{array}$} & \multirow[b]{2}{*}{$\begin{array}{l}\text { Mean } \\
\text { Square }\end{array}$} & \multicolumn{3}{|c|}{ F. Required odds } \\
\hline & & & & Found & $99: 1$ & $19: 1$ \\
\hline Total & 89 & $57,275 \cdot 66$ & 648.55 & - & - & - \\
\hline $\begin{array}{l}\mathrm{K}_{2} \mathrm{HPO}_{4} \\
\mathrm{MgSO}_{4}\end{array}$ & $\mathbf{2}$ & $\begin{array}{r}34,966 \cdot 43 \\
1,298 \cdot 02\end{array}$ & $\begin{array}{r}17,483 \cdot 22 \\
649 \cdot 01\end{array}$ & $\begin{array}{r}60 \cdot 14 \\
2 \cdot 57\end{array}$ & $\begin{array}{l}4 \cdot 88 \\
4 \cdot 88\end{array}$ & $\begin{array}{l}3 \cdot 11 \\
3 \cdot 11\end{array}$ \\
\hline $\mathrm{KCl}$ & 1 & $31 \cdot 21$ & 31.21 & - & - & - \\
\hline $\mathrm{K}_{2} \mathrm{HPO}_{4} \times \mathrm{MgSO}_{4}$ & 4 & $1,098 \cdot 31$ & 274.58 & $\mathbf{3 . 9 9}$ & $4 \cdot 88$ & $3 \cdot 11$ \\
\hline $\mathrm{K}_{2} \mathrm{HPO}_{4} \times \mathrm{KCl}$ & 2 & $502 \cdot 49$ & $251 \cdot 25$ & - & - & - \\
\hline $\mathrm{MgSO}_{4} \times \mathrm{KCl}$ & 2 & $192 \cdot 96$ & 96.48 & - & - & 一 \\
\hline $\begin{array}{l}\text { 2nd order interaction } \\
\text { error }\end{array}$ & 76 & $19,217 \cdot 45$ & $252 \cdot 86$ & - & - & - \\
\hline
\end{tabular}

Second factorial experiment: variation of amounts of $\mathrm{K}_{2} \mathrm{HPO}_{4}$ and $\left(\mathrm{NH}_{4}\right)_{2} \mathrm{SO}_{4}$ added

This experiment was complementary to the first factorial experiment and sought to determine the relation between $\mathrm{K}_{2} \mathrm{HPO}_{4}$ and $\left(\mathrm{NH}_{4}\right)_{2} \mathrm{SO}_{4}$ in the medium $A$. The concentrations were: $\mathrm{K}_{2} \mathrm{HPO}_{4}, 0.008,0.012$ and $0.016 \mathrm{M}$; and $\left(\mathrm{NH}_{4}\right)_{2} \mathrm{SO}_{4}, 0.0125,0.025$ and $0.0875 \mathrm{M}$. The concentration of $\mathrm{MgSO}_{4}$ was constant at $0.003 \mathrm{M} ; \mathrm{KCl}$ was omitted. The other constituents of the medium and the conditions of growth were as in the previous experiment. The results 
are given in Table 2. It was again noticed that in each culture a favourable initial $\mathrm{pH}$ value between $7 \cdot 0$ and 8.0 fell to $c . \mathrm{pH} \mathrm{2.0}$ when growth ceased.

The salts $\left(\mathrm{NH}_{4}\right)_{2} \mathrm{SO}_{4}$ and $\mathrm{K}_{2} \mathrm{HPO}_{4}$ taken singly show no significant effect except $\mathrm{K}_{2} \mathrm{HPO}_{4}$ at the 19:1 level only. The interaction of these salts, however, produced a highly significant effect at both probability levels, and hence a balance existed between them. Table 2 shows that no growth benefit was obtained by increasing the concentrations of $\left(\mathrm{NH}_{4}\right)_{2} \mathrm{SO}_{4}$ at the $\mathrm{P}_{1}$ level, while at the $\mathrm{P}_{2}$ level a very large increase in dry weight was noticed with increasing nitrogen concentration. At the $P_{3}$ level a similar increase in growth was

Table 2. Dry weight of mycelium and growth responses of Rhizopus stolonifer after 7 days growth at $26^{\circ}$ in media with varying concentrations of $\mathrm{K}_{2} \mathrm{HPO}_{4}$ and $\left(\mathrm{NH}_{4}\right)_{2} \mathrm{SO}_{4}$

Concentrations of $\mathrm{K}_{2} \mathrm{HPO}_{4}: \mathrm{P}_{1}, \mathrm{P}_{2}, \mathrm{P}_{3}=0.008 \mathrm{M}, 0.012 \mathrm{M}, 0.016 \mathrm{M}$; of $\left(\mathrm{NH}_{4}\right)_{2} \mathrm{SO}_{4}: \mathrm{N}_{1}, \mathrm{~N}_{2}$, $\mathrm{N}_{3}=0.125 \mathrm{M}, 0.025 \mathrm{M}, 0.0375 \mathrm{M}$. Difference required between weights for odds of $99: 1=$ $13 \cdot 22$ mg. Results given as mg. mean dry wt./mycelium.

$\begin{array}{lcccc} & \mathbf{N}_{1} & \mathbf{N}_{2} & \mathbf{N}_{3} & \text { Mean } \\ \mathbf{P}_{1} & 123 & 126 & 123 & 124 \\ \mathbf{P}_{2} & 139 & 159 & 177 & 158 \\ \mathbf{P}_{3} & 130 & 197 & 171 & 166 \\ \text { Mean } & 131 & 161 & 157 & -\end{array}$

General mean $=149.5 \mathrm{mg}$. dry wt. $/$ flask.

\section{Analysis of variance}

Required ' $F$ ' and ' $t$ ' values from Snedecor's tables (1934).

\begin{tabular}{|c|c|c|c|c|c|c|}
\hline \multirow[b]{2}{*}{ Variance } & \multirow[b]{2}{*}{ D.F. } & \multirow[b]{2}{*}{$\begin{array}{l}\text { Sum of } \\
\text { squares }\end{array}$} & \multirow[b]{2}{*}{$\begin{array}{c}\text { Mean } \\
\text { squares }\end{array}$} & \multicolumn{3}{|c|}{$F$. Required odds } \\
\hline & & & & Found & $99: 1$ & $19: 1$ \\
\hline Total & 44 & $41,082 \cdot 8$ & $933 \cdot 7$ & - & - & - \\
\hline $\begin{array}{l}\mathrm{K}_{2} \mathrm{HPO}_{4} \\
\left(\mathrm{NH}_{4}\right)_{2} \mathrm{SO}_{4} \\
\mathrm{~K}_{2} \mathrm{HPO}_{4} \times\left(\mathrm{NH}_{4}\right)_{2} \mathrm{SO}_{4}\end{array}$ & $\begin{array}{r}2 \\
2 \\
4\end{array}$ & $\begin{array}{r}15,241 \cdot 73 \\
8,284 \cdot 13 \\
7,184 \cdot 54\end{array}$ & $\begin{array}{l}7620 \cdot 87 \\
4142 \cdot 07 \\
1796 \cdot 14\end{array}$ & $\begin{array}{l}4 \cdot 24 \\
2 \cdot 30 \\
6 \cdot 24 *\end{array}$ & $\begin{array}{l}4 \cdot 29 \\
4 \cdot 92 \\
3 \cdot 60^{*}\end{array}$ & $\begin{array}{l}\mathbf{3} \cdot 13 \\
\mathbf{3} \cdot 13 \\
\mathbf{2} \cdot \mathbf{5 0}\end{array}$ \\
\hline Error & 36 & $10,372 \cdot 4$ & $288 \cdot 12$ & - & & \\
\hline
\end{tabular}

* Note: where only one first-order interaction is significant and it is of greater magnitude than the error, then the mean square for the interaction is used in the determination of ' $F$ ' values in place of the error.

obtained, but there was no significant difference between these two levels themselves. At the point of maximum dry weight of mycelium, i.e. when growth has ceased (somewhere between $P_{2}$ and $P_{3}$ ), chemical analysis showed that nitrogen was still present in the medium; thus $\left(\mathrm{NH}_{4}\right)_{2} \mathrm{SO}_{4}$ was not then limiting further growth. In both factorial experiments growth ceased when the $\mathrm{pH}$ value fell to $c .2 \cdot 0$. In the first experiment a balance was not found to exist between the salt constituents of the medium, but growth increased steadily with increasing concentration of phosphate hence the $\mathrm{K}_{2} \mathrm{HPO}_{4}$ acted as an essential nutrient. In the second factorial experiment a balance between $\mathrm{K}_{2} \mathrm{HPO}_{4}$ and $\left(\mathrm{NH}_{4}\right)_{2} \mathrm{SO}_{4}$ was found to exist. The writers have already shown (1956) that a suitably buffered medium containing $0.025 \mathrm{M}-\left(\mathrm{NH}_{4}\right)_{2} \mathrm{SO}_{4}$ will 
produce up to about $300 \mathrm{mg}$. dry-weight mycelium and then the $\left(\mathrm{NH}_{4}\right)_{2} \mathrm{SO}_{4}$ begins to exert a limiting effect. It is possible then that in this experiment $\mathrm{K}_{2} \mathrm{HPO}_{4}$ also acted as a buffer. Thus buffering capacity of media becomes of importance in growth.

\section{Variation of amounts of $\left(\mathrm{NH}_{4}\right)_{2} \mathrm{SO}_{4}$ and glucose added}

In the preceding experiments the media contained $4 \%(\mathrm{w} / \mathrm{v})$ glucose which gave a satisfactory growth and ensured that this substance did not limit growth by becoming exhausted in the medium. The experiment below describes the effect of varying the amount of glucose in the medium. Two sets of media were made up each containing $0.012 \mathrm{M}-\mathrm{K}_{2} \mathrm{HPO}_{4} ; 0.003 \mathrm{M}-\mathrm{MgSO}_{4} .7 \mathrm{H}_{2} \mathrm{O}$; trace metals 2 p.p.m. and glucose at 1, 2, 4, or $8 \%$; and either 0.0125 or $0.025 \mathrm{M}$ $\left(\mathrm{NH}_{4}\right)_{2} \mathrm{SO}_{4}$. Thus there were twenty-four different solutions with four concentrations of glucose and two concentrations of $\left(\mathrm{NH}_{4}\right)_{2} \mathrm{SO}_{4}$. The cultures were incubated as previously described. Four flasks of each variation of medium were withdrawn after 2 days growth, four more after 5 days and the remainder after 7 days growth. Thus it was possible to assess rate of growth as well as dry weight of the mycelium. The results are shown in Table 3.

Table 3. Growth responses of Rhizopus stolonifer to variations in. concentrations of glucose and $\left(\mathrm{NH}_{4}\right)_{2} \mathrm{SO}_{4}$

Concentrations of $\left(\mathrm{NH}_{4}\right)_{2} \mathrm{SO}_{4}: \mathrm{N}_{1}=0.0125 \mathrm{M}, \mathrm{N}_{2}=0.025 \mathrm{M}$. Results given as mg. dry wt./ mycelium. Initial pH: $\mathbf{N}_{1}=7 \cdot 25, \mathbf{N}_{8}=7 \cdot 42$.

\begin{tabular}{|c|c|c|c|c|}
\hline \multirow{2}{*}{$\begin{array}{l}\text { Time } \\
\text { in days }\end{array}$} & \multirow{2}{*}{$\begin{array}{l}\text { Percentage } \\
\text { concentration } \\
\text { glucose }\end{array}$} & \multirow{2}{*}{$\begin{array}{c}\text { Variation } \\
\text { of final } \\
\text { pH }\end{array}$} & \multicolumn{2}{|c|}{ Mean wt. in } \\
\hline & & & $\mathbf{N}_{1}$ & $\mathbf{N}_{2}$ \\
\hline 2 & $\begin{array}{l}1 \\
2 \\
4 \\
8\end{array}$ & $\begin{array}{l}6 \cdot 42-6 \cdot 88 \\
6 \cdot 27-6 \cdot 5 \\
5 \cdot 9-6 \cdot 5 \\
5 \cdot 88-6 \cdot 3\end{array}$ & $\begin{array}{l}13 \\
26 \\
40 \\
63\end{array}$ & $\begin{array}{l}12 \\
34 \\
38 \\
71\end{array}$ \\
\hline 5 & $\begin{array}{l}1 \\
2 \\
4 \\
8\end{array}$ & $\begin{array}{l}2 \cdot 38-2 \cdot 51 \\
2 \cdot 03-2 \cdot 18 \\
2 \cdot 01-2 \cdot 19 \\
1 \cdot 98-2 \cdot 18\end{array}$ & $\begin{array}{r}91 \\
141 \\
150 \\
183\end{array}$ & $\begin{array}{l}100 \\
143 \\
169 \\
190\end{array}$ \\
\hline 7 & $\begin{array}{l}1 \\
2 \\
4 \\
8\end{array}$ & $\begin{array}{l}2 \cdot 56-2 \cdot 76 \\
2 \cdot 1-2 \cdot 19 \\
2 \cdot 05-2 \cdot 17 \\
2 \cdot 0-2 \cdot 17\end{array}$ & $\begin{array}{r}72 \\
127 \\
132 \\
171\end{array}$ & $\begin{array}{r}89 \\
143 \\
161 \\
199\end{array}$ \\
\hline
\end{tabular}

At all periods after 2 days an increase of glucose concentration from 1 to $8 \%$ showed a steady increase in mycelial weight. In each time period the greatest weight was obtained with $8 \%$ glucose. At both concentrations of $\left(\mathrm{NH}_{4}\right)_{2} \mathrm{SO}_{4}$ an increase of glucose concentration greater than $1 \%$ brought about a decrease in the length of the lag period, although after the second day the growth rates are all comparable. With a solution containing $0.025 \mathrm{M}-\left(\mathrm{NH}_{4}\right)_{2} \mathrm{SO}_{4}$ there was only a slight increase in weight compared with the solution at the $0.0125 \mathrm{M}$ level at concentrations of 1,2 and $8 \%$ glucose; but at $4 \%$ glucose after 5 and 7 days growth $0.025 \mathrm{M}-\left(\mathrm{NH}_{4}\right)_{2} \mathrm{SO}_{4}$ produced significantly higher weights of mycelium. 
In this experiment the grand period of growth extended from after the second to the fifth day when the $\mathrm{pH}$ value fell to about $2 \cdot 0$, and in general the highest weights of mycelium were obtained on this day and thereafter there was a small drop. Growth ceases when the $\mathrm{pH}$ value reaches about 2.0 but usually this did not occur until the 6th to 7th day. During all periods the cultures with the $1 \%$ glucose concentration showed an appreciably higher $\mathrm{pH}$ compared with the 2,4 and $8 \%$ levels of glucose.

\section{Rate of growth}

In this nutritional study the grow th criterion has been dry weight of mycelium and the growth period was fixed at 6-7 days. The following experiment showed the effect of two other growth criteria, namely length of lag period and rate of growth. Two media were used for this purpose : $(a)$ one of the optimal solutions from the second factorial experiment containing $0.012 \mathrm{M}-\mathrm{K}_{2} \mathrm{HPO}_{4} ; 0.003 \mathrm{M}$ $\mathrm{MgSO}_{4} .7 \mathrm{H}_{2} \mathrm{O} ; 0.025 \mathrm{M}-\left(\mathrm{NH}_{4}\right)_{2} \mathrm{SO}_{4} ; 4 \%(\mathrm{w} / \mathrm{v})$ glucose; and $\mathrm{Zn}, \mathrm{Fe}, \mathrm{Mn}$ at 2 p.p.m.; and $(b)$ a solution which gave a minimal response containing $0.004 \mathrm{M}-\mathrm{K}_{2} \mathrm{HPO}_{4}$ and $0.0125 \mathrm{M}-\left(\mathrm{NH}_{4}\right)_{2} \mathrm{SO}_{4}$ with the other ingredients as above. Thirty-five flasks of each medium were set up and incubated as usual. After the first day's growth five flasks of each culture were removed each day for 8 days. The initial and final $\mathrm{pH}$ values were recorded and the results expressed as dry wt./mycelium. This experiment was carried out twice and the results are shown in Fig. 1.

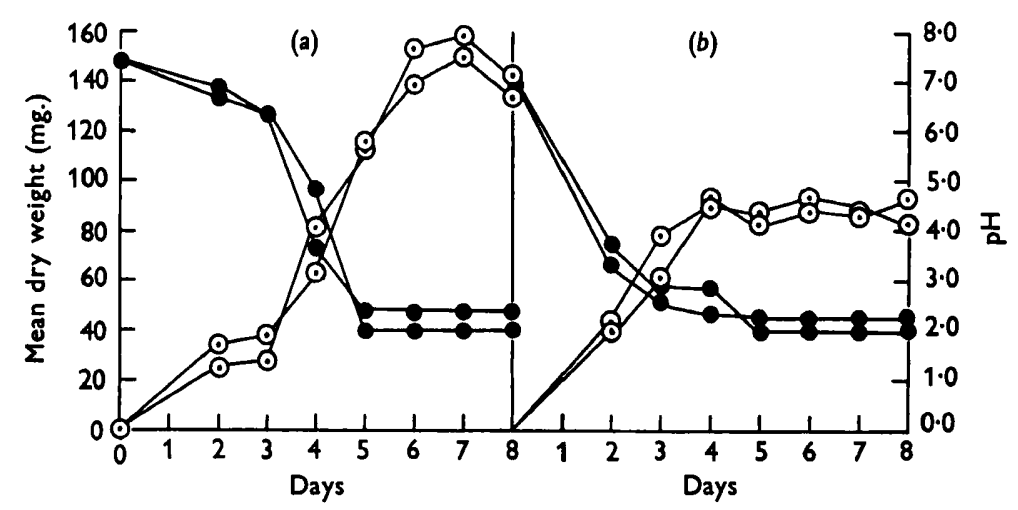

Fig. 1. Rate of growth and $\mathrm{pH}$ changes of Rhizopus stolonifer growing in optimal (a) and minimal $(b)$ media (two experiments). $-\bullet, \mathrm{pH} ; \odot-\odot$, dry weight.

The optimal medium showed a 3-day lag period which coincided with germination, initial uptake of nutrients and the primary assimilation period. After the third day the grand period of growth set in rapidly. This rapid acceleration of growth was accompanied by a rapid drop in $\mathrm{pH}$ which probably coincided with the differential uptake of $\mathrm{NH}_{4}^{+}$ions in preference to $\mathrm{SO}_{4}^{--}$ions in the medium (see Fothergill \& Yeoman, 1956). Maximum growth occurred between $\mathrm{pH}$ values $6 \cdot 4$ and about $2 \cdot 0$, although a preliminary experiment showed that an initial $\mathrm{pH}$ value of $6 \cdot 4$ ultimately gave a decrease in dry weight of the mycelium. In the optimal medium the grand period of growth was 
followed by a drop in dry weight. On the other hand, the minimal medium showed a much shorter lag period of about $36 \mathrm{hr}$. The maximum dry weight was attained by the 4th day and it then persisted at a constant level throughout the remainder of the experimental period. The decline in dry weight had not set in with this medium even by the 8th day. The maximum rate of growth with this medium occurred after the $\mathrm{pH}$ values had fallen to between 3.0 and 2.0. Thus in the optimal solution the growth followed a typical pattern giving a normal sigmoid growth curve such as we expect in a normally metabolizing organism. In the minimal medium, however, growth became constant at a relatively early stage and with a low mycelial production. It is probable that in this medium the nutrients $\mathrm{K}_{2} \mathrm{HPO}_{4}$ or $\left(\mathrm{NH}_{4}\right)_{2} \mathrm{SO}_{4}$ were exerting a limiting effect on growth.

\section{The importance of a balanced solution}

It has already been shown in the first factorial experiment that a balance between the mineral salts was not required for good growth when $\left(\mathrm{NH}_{4}\right)_{2} \mathrm{SO}_{4}$ was at a constant concentration in the medium. In the third factorial experiment described below $\mathrm{K}_{2} \mathrm{HPO}_{4}$ and $\mathrm{MgSO}_{4}$ were varied in a manner which would maintain the same balance between them in all solutions but which altered the ratio between the salts in different sets of media. Four treatments were given and in each the balance of these two salts was in the ratios 0.5 : $1 \cdot 0: 2 \cdot 0: 4 \cdot 0$, when unity was represented by $0 \cdot 012 \mathrm{M}-\mathrm{K}_{2} \mathrm{HPO}_{4}$ and $0 \cdot 003 \mathrm{M}-$ $\mathrm{MgSO}_{4} \cdot 7 \mathrm{H}_{2} \mathrm{O}$. Each of these four treatments was tested with $\left(\mathrm{NH}_{4}\right)_{2} \mathrm{SO}_{4}$ at concentrations of $0.0125,0.025$ and $0.05 \mathrm{M}$. The other ingredients in the media and the conditions of experiment were as before. The results were expressed as mg. dry wt./mycelium and they are shown in Table $4 A$ and $B$ which also includes the calculation for ' $t$ ' determining the significance of the deviation between the mean dry weights.

These results indicated that treatments 3 and 2, 4 and 3, and 12 and 11 were not significantly different, while the others were different. It seems clear that the lower levels of all the salts produced a lower dry weight of mycelium up to treatment 6. After this treatment, even with the highest concentration of $\left(\mathrm{NH}_{4}\right)_{2} \mathrm{SO}_{4}$, the lower concentrations of $\mathrm{K}_{2} \mathrm{HPO}_{4}$ and $\mathrm{MgSO}_{4}$ in treatments 9 and 10 still produced a low dry weight of mycelium. This experiment confirmed the previous conclusion that there is no balance between $\mathrm{K}_{2} \mathrm{HPO}_{4}$ and $\mathrm{MgSO}_{4}$, but it also indicated that a balance of these salts with $\left(\mathrm{NH}_{4}\right)_{2} \mathrm{SO}_{4}$ was necessary for good growth. The significant effect of this balance became evident from the mean growth responses and interactions in Table $4 B$. At the 0.5 and 1.0 salt ratios the buffer capacity of the phosphate must have been limiting growth because increasing the concentration of $\left(\mathrm{NH}_{4}\right)_{2} \mathrm{SO}_{4}$ had only little effect upon the mycelial yields. By increasing the $\left(\mathrm{NH}_{4}\right)_{2} \mathrm{SO}_{4}$ concentrations at the 2.0 salt ratios an increase in dry weight was brought about; at this ratio buffer capacity probably became limiting only at the highest concentration of $\left(\mathrm{NH}_{4}\right)_{2} \mathrm{SO}_{4}$. Finally, with the 4.0 salt ratio an increase in the nitrogen concentration from $0.0125 \mathrm{M}$ to $0.025 \mathrm{M}$ gave a highly significant effect and produced the best mycelial growth of all the experiments. By further raising the nitrogen 
concentration to $0.05 \mathrm{M}$ no further significant effect was produced. In this case the acidity concomitant with the higher nitrogen concentration was limiting growth. Thus it is apparent that no significant increase of dry weight will result in media such as these by increasing the buffer capacity while the nitrogen salt is limiting, or by raising the concentration of $\left(\mathrm{NH}_{4}\right)_{2} \mathrm{SO}_{4}$ while the buffer capacity is limiting. It may be concluded that the importance of the balance existing between the combined mineral salts and $\left(\mathrm{NH}_{4}\right)_{2} \mathrm{SO}_{4}$ lies in the buffering capacity of the mineral salts. $\mathrm{As}_{\mathrm{MgSO}_{4}}$ is not a buffering agent the true balance in this medium is between $\mathrm{K}_{2} \mathrm{HPO}_{4}$ and $\left(\mathrm{NH}_{4}\right)_{2} \mathrm{SO}_{4}$. If then

Table 4. Dry reight of mycelia $(A)$ and mean growth responses $(B)$ of Rhizopus stolonifer to different ratios of $\mathrm{K}_{2} \mathrm{HPO}_{4}$ and $\mathrm{MgSO}_{4}$ with the same balance and different concentrations of $\left(\mathrm{NH}_{4}\right)_{2} \mathrm{SO}_{4}$

Molar concentrations of $\mathrm{K}_{2} \mathrm{HPO}_{4}: \mathrm{P}_{1}, \mathrm{P}_{2}, \mathrm{P}_{3}, \mathrm{P}_{4}=0.006,0.012,0.024,0.048$; of $\mathrm{MgSO}_{4}$ : $\mathrm{Mg}_{1}, \mathrm{Mg}_{2}, \mathrm{Mg}_{3}, \mathrm{Mg}_{4}=0.0015,0.003,0.006,0.012$; of $\left(\mathrm{NH}_{4}\right)_{2} \mathrm{SO}_{4}: \mathrm{N}_{1}, \mathrm{~N}_{2}, \mathrm{~N}_{3}=0.0125,0.025$ $0 \cdot 05$. Initial $\mathrm{pH}=7 \cdot 62-6 \cdot 85$. Value of ' $t$ ' required at the $99: 1$ level for differences to be signiflcant is $\mathbf{2 \cdot 4 4 7}$. Results given as mg. mean dry wt./mycelium.

A. Dry wt. mycelia

\begin{tabular}{|c|c|c|c|c|c|c|c|}
\hline \multirow{2}{*}{$\begin{array}{c}\text { Treatment } \\
\text { soln. } \\
\text { no. }\end{array}$} & \multicolumn{3}{|c|}{ Salts } & \multirow{2}{*}{$\begin{array}{l}\text { Range of } \\
\text { final pH }\end{array}$} & \multirow{2}{*}{$\begin{array}{l}\text { Mean wt. } \\
\text { mycelium }\end{array}$} & \multirow[b]{2}{*}{ Differences } & \multirow[b]{2}{*}{ ' $t$ ' } \\
\hline & $\mathbf{P}$ & $\mathbf{M g}$ & $\mathbf{N}$ & & & & \\
\hline 1 & $\mathbf{P}_{1}$ & $\mathbf{M g}_{1}$ & $\mathbf{N}_{1}$ & $2 \cdot 06-2 \cdot 1$ & 100 & - & - \\
\hline 2 & $\mathbf{P}_{2}$ & $\mathbf{M g}_{2}$ & $\mathrm{~N}_{1}$ & $2 \cdot 1-2 \cdot 2$ & 157 & 57 & $5 \cdot 451$ \\
\hline $\mathbf{3}$ & $\mathbf{P}_{3}$ & $\mathrm{Mg}_{\mathbf{8}}$ & $\mathbf{N}_{1}$ & $2 \cdot 85-3 \cdot 1$ & 142 & 15 & 1.511 \\
\hline 4 & $\mathbf{P}_{4}$ & $\mathrm{Mg}_{4}$ & $\mathbf{N}_{1}$ & $3 \cdot 44-8 \cdot 68$ & 151 & $\mathbf{9}$ & $1 \cdot 697$ \\
\hline 5 & $\mathbf{P}_{1}$ & $\mathrm{Mg}_{1}$ & $\mathbf{N}_{2}$ & $2 \cdot 13-2 \cdot 23$ & 110 & 41 & 4.941 \\
\hline 6 & $\mathbf{P}_{\mathbf{2}}$ & $\mathrm{Mg}_{\mathbf{g}}$ & $\mathbf{N}_{2}^{*}$ & $2 \cdot 13-2 \cdot 2$ & 141 & 31 & $2 \cdot 766$ \\
\hline 7 & $\mathbf{P}_{3}$ & $\mathrm{Mg}_{8}$ & $\mathbf{N}_{2}$ & $2 \cdot 19-2 \cdot 36$ & 198 & 57 & $4 \cdot 778$ \\
\hline 8 & $\mathbf{P}_{4}$ & $\mathrm{Mg}_{4}$ & $\mathbf{N}_{2}$ & $2 \cdot 96-3 \cdot 0$ & 240 & 42 & 3.027 \\
\hline $\boldsymbol{\theta}$ & $\mathbf{P}_{1}$ & $\mathbf{M g}_{1}$ & $\mathbf{N}_{3}$ & $2 \cdot 2-2 \cdot 28$ & 122 & 118 & $10 \cdot 26$ \\
\hline 10 & $\mathbf{P}_{\mathbf{g}}$ & $\mathrm{Mg}_{\mathrm{g}}$ & $\mathbf{N}_{3}^{\circ}$ & $2 \cdot 20-2 \cdot 23$ & 140 & 18 & $2 \cdot 534$ \\
\hline 11 & $\mathbf{P}_{8}$ & $\mathrm{Mg}_{3}$ & $\mathbf{N}_{\mathbf{3}}$ & $2 \cdot 15-2 \cdot 32$ & 232 & 92 & $4 \cdot 843$ \\
\hline 12 & $\mathbf{P}_{4}$ & $\mathrm{Mg}_{4}$ & $\mathbf{N}_{8}$ & $2 \cdot 85-2 \cdot 94$ & 235 & $\mathbf{3}$ & $<1$ \\
\hline
\end{tabular}

B. Mean growth response and interactions

Salts $=\mathrm{K}_{2} \mathrm{HPO}_{4}$ and $\mathrm{MgSO}_{4}$; figures in brackets = treatment nos.

\begin{tabular}{|c|c|c|c|c|}
\hline \multirow{2}{*}{$\begin{array}{c}\left(\mathbf{N H}_{4}\right)_{2} \mathrm{SO}_{4} \\
\text { concn. } \\
\mathbf{N}_{1} \\
\mathbf{N}_{2} \\
\mathbf{N}_{3}\end{array}$} & \multirow{2}{*}{$\begin{array}{c}\text { Mean wt. } \\
\text { mycelium } \\
188 \\
172 \\
182\end{array}$} & \multicolumn{3}{|c|}{$\begin{array}{c}\text { Interaction salt } \\
\text { ratio } \times\left(\mathrm{NH}_{4}\right)_{2} \mathrm{SO}_{4} \mathrm{mg} .\end{array}$} \\
\hline & & $\begin{array}{r}0.5 \times \mathbf{N}_{1} \\
\times \mathbf{N}_{8} \\
\times \mathbf{N}_{3}\end{array}$ & $\begin{array}{l}100 \\
110 \\
122\end{array}$ & $\begin{array}{l}\text { (1) } \\
\text { (5) } \\
\text { (9) }\end{array}$ \\
\hline Salt & $\mathbf{M}$ & $\begin{array}{r}1.0 \times N_{1} \\
\times N_{2} \\
\times N_{8}\end{array}$ & $\begin{array}{l}157 \\
141 \\
140\end{array}$ & $\begin{array}{r}(2) \\
(6) \\
(10)\end{array}$ \\
\hline $\begin{array}{c}\text { concn. } \\
0.5 \\
1.0\end{array}$ & $\begin{array}{c}\text { mycelium } \\
111 \\
146\end{array}$ & $\begin{array}{r}\mathbf{2 \cdot 0} \times \mathbf{N}_{1} \\
\times \mathbf{N}_{2} \\
\times \mathbf{N}_{8}\end{array}$ & $\begin{array}{l}142 \\
198 \\
232\end{array}$ & $\begin{array}{r}(3) \\
(7) \\
(11)\end{array}$ \\
\hline $\begin{array}{l}2 \cdot 0 \\
4 \cdot 0\end{array}$ & $\begin{array}{l}191 \\
200\end{array}$ & $\begin{array}{r}4.0 \times N_{1} \\
\times N_{2} \\
\times N_{8}\end{array}$ & $\begin{array}{l}151 \\
240 \\
285\end{array}$ & $\begin{array}{r}(4) \\
(8) \\
(12)\end{array}$ \\
\hline
\end{tabular}


the acidity of the medium plays such a large part in determining the amount of mycelial growth, by using better buffering agents than $\mathrm{K}_{2} \mathbf{H P O}_{4}$ mycelial growth should be greatly increased. In fact, as already mentioned, the writers (1956) have shown elsewhere that by using anhydrous sodium succinate, which does not act as a significant nutrient for this fungus in this medium but which is an excellent buffer, mean dry mycelial weights of nearly $300 \mathrm{mg}$. have been obtained. When $\mathrm{K}_{2} \mathrm{HPO}_{4}$ is used as a nutrient and as a buffer the highest yield of mycelium is obtained when the fungus is grown for 6-7 days at $26^{\circ}$ in a liquid medium containing: $4 \%(\mathrm{w} / \mathrm{v})$ glucose; $0.048 \mathrm{M}-\mathrm{K}_{2} \mathrm{HPO}_{4} ; 0.012 \mathrm{M}$ $\mathrm{MgSO}_{4} .7 \mathrm{H}_{2} \mathrm{O} ; 0.025 \mathrm{M}-\left(\mathrm{NH}_{4}\right)_{2} \mathrm{SO}_{4}$; and $\mathrm{Zn}, \mathrm{Fe}, \mathrm{Mn}$ at 2 p.p.m.

Morton \& Macmillan (1954) carried out an extensive study of the assimilation of nitrogen from ammonium salts and nitrate by several fungi in which they showed that, in the presence of ammonium salts, various organic acids act as buffers. The chief fungus they worked with was Scopulariopsis brevicaulis, but this is a fungus which uses $\mathrm{KNO}_{3}$ alone, unlike Rhizopus. Their results, however, are not strictly comparable with those presented here for the above reason and also because they did not analyse the effect of $\mathrm{KH}_{2} \mathrm{PO}_{4}$, present in their basal medium, on the assimilation of ammonium. Nevertheless, these experiments confirm those of Morton and Macmillan by showing that assimilation of ammonium is greatly increased in the presence of $\mathrm{K}_{2} \mathrm{HPO}_{4}$ acting as a buffer. The writers (1956) have already shown by chromatographic analysis that in a medium containing $\left(\mathrm{NH}_{4}\right)_{2} \mathrm{SO}_{4}$, sulphuric acid forms in the medium and the phosphate buffers this substance. Inert buffers, like 'Sigma' buffer (2-amino-2-hydroxymethylpropane-1:3-diol) act better than phosphate, and acetate and succinate act best of all. It seems in fact if all these results are considered that growth is proportional to buffer capacity and the latter may become an important growth-limiting factor.

The authors would like to thank their colleague Mr H. Campbell, B.A., F.S.S., for his kind help with the statistics.

\section{REFERENCES}

Fothergill, P. G. \& Ashcroft, R. (1955). The nutritional requirements of Venturia inaequalis. J. gen. Microbiol. 12, 387.

Fothergill, P. G. \& Raine, L. C. D. P. (1954). The mineral nutritional requirements of Mucor hiemalis Wehm. J. gen. Microbiol. 10, 17.

Fothergill, P. G. \& Yeoman, M. M. (1956). Acidity and growth of Rhizopus stolonifer in mineral culture media. Bull. Jard. bot. Brux. 26, 371.

Morton, A. G. \& Macmillan, A. (1954). The assimilation of nitrogen from ammonium salts and nitrate by fungi. J. exp. Bot. 5, 232.

Robrins, W. J. (1924). Isoelectric points for the mycelium of fungi. J. gen. Physiol. 6, 259.

Robins, W. J. (1937). The assimilation by plants of various forms of nitrogen. Amer. J. Bot. 24, 243.

SNEDECOR, G. W. (1934). Calculation and interpretation of analysis of variance and co-variance. Iowa St. Coll. Div. Indust. Sci. Monogr. 1. Ames, Iowa.

Talley, P. J. \& Blank, R. L. M. (1941). A critical study of the nutritional requirements of Phymatotrichum omnivorum. Plant Physiol. 16, 1.

(Received 17 May 1957) 